\title{
Water budget for south Texas rangelands
}

\author{
MARK A. WELTZ AND WILBERT H. BLACKBURN
}

Authors are hydrologist, Southwest Watershed Research Center, 2000 E. Allen Rd., Tucson, Ariz. 85719: and hydrologist, Narthem Plains Area Office, 1201 Oakridge, Suite 150, Fort Collins, Colo. 80525.

\begin{abstract}
Understanding hydrologic processes is essential to determine if water yield augmentation is possible through vegetation manipulation. Nine large non-weighing lysimeters, each $35 \mathrm{~m}^{2}$, were installed on the La Copita Research Area, $20 \mathrm{~km}$ south of Alice, in the eastern Rio Grande Plain of Texas. The non-weighing lysimeters were used to test the hypothesis that honey mesquite (Prosopis glandulosa var glandulosa Torr.) shrub clusters have greater evapotranspiration rates than grass interspaces. Annual evapotranspiration rates of shrub clusters and grass interspaces were found to be similar, and both were significantly greater than evaporative losses from bare soil. Surface runoff and deep drainage of water ( $>2 \mathrm{~m}$ ) from the bare soil were significantly greater than from the grass interspaces and shrub clusters. There was no drainage of water below $2 \mathrm{~m}$ from the shrub clusters. A total of $22 \mathrm{~mm}$ of water percolated below $2 \mathrm{~m}$ from the grass interspace during the 18 month study period. These results indicate that no net change in the water budget would occur if shrub clusters were replaced with grasses in years with below average or normal rainfall. Increasing water yield from converting shrub-dominated rangelands to grass-dominated rangelands in south Texas is marginal in this area and limited to years when winter and spring rainfall exceeds potential evapotranspiration. There is little evidence to suggest that the minimal (non-significant difference) increase in percolation and surface runoff from the grass interspaces could be reliably captured and dependably made available off-site.
\end{abstract}

Key Words: Evapotranspiration, runoff, soil water, drainage, lysimeter, water yield.

Controlling honey mesquite (Prosopis glandulosa var glandulosa Torr.) has traditionally been related to increased forage production (Scifres and Polk 1974, Brock et al. 1978, Bedunah and Sosebee 1984, Heitschmidt et al. 1986). Recently it has been suggested that an additional benefit of controlling honey mesquite would be increased water yield (Griffin and McCarl 1989). Investigations began several decades ago into the relationships among plants, soil water and land use on rangelands. A simple water balance model to express the total potential water yield that could be harvested from rangeland watersheds, ignoring, runon

Manuscript accepted 12 Apr. 1993. can be expressed as:

$$
\text { Water yield }=\mathrm{PPT}-\mathrm{EY} \pm \mathrm{S}
$$

where water yield includes surface and subsurface flow, and any percolation to groundwater; PPT is precipitation; ET is evapotranspiration; and $S$ is the change in water stored in the soil profile or regolith (Hibbert 1979). If evapotranspiration can be reduced by altering vegetation, water yield will increase, the magnitude of which depends on the change in stored soil water.

Numerous studies have evaluated the water budget of forest and scrub woodlands, and excellent reviews of the literature are provided by Bosch and Hewlett (1982) and Hibbert (1983). Relatively few studies have evaluated components of the water budget for mesquite-dominated rangelands (Richardson et al. 1979, Carlson et al. 1990). Rechenthin and Smith (1964) estimated that a comprehensive vegetation manipulation program could save 12,000 million $\mathrm{m}^{3}$ of water in the Rio Grande Plains of Texas. The estimate was based on research conducted primarily in Arizona and California. They assumed that removal of woody plants would reduce evapotranspiration, increase soil water content and forage production, and significantly increase water yield. There is little data available from south Texas rangelands to support or refute this estimate.

Walter (1971) proposed a 2-layer soil-water system to explain water use and the stability of savannahs. He proposed that herbaceous vegetation was a superior competitor for water in the topsoil and that woody plants had exclusive access to subsoil water. Knoop and Walker (1985) evaluated 2 savannah communities in South Africa to test this hypothesis. In an Acacia community with 7 fold more herbaceous biomass, mature woody-plant growth was reduced from competition with herbaceous vegetation. Their soil water and root distribution data indicated that herbaceous vegetation utilization of water in the topsoil was sufficient to reduce drainage into the subsoil. Herbaceous vegetation also withdrew water directly from the subsoil in direct competition with woody plants.

Heitschmidt and Dowhower (1991) and Carlson et al. (1990) evaluated the effect of removal of honey mesquite in Texas on herbage response and water balance. They reported that annual above-ground net primary productivity increased significantly following removal of honey mesquite. The increase was the result of increased production of the species present at the time of control rather than a shift in species composition. Evapotranspiration accounted for $95 \%$ of rainfall from both sites. They reported no 
net change in evapotranspiration, runoff, or drainage associated with removal of honey mesquite. Increased annual above-ground net primary productivity of the treated site offset any water yield benefit that accrued through removal of honey mesquite trees. Dugas and Mayeux (1991) reported that both percentage and absolute difference in evapotranspiration between treated and untreated mesquite dominated rangelands were greatest under dry conditions and were essentially zero immediately after rainfall. While mesquite used substantial amounts of water, evapotranspiration from rangelands with mesquite that was killed was essentially the same due to the increased annual above-ground net primary productivity of other species following mesquite control.

Two honey mesquite-dominated watersheds were evaluated in the Blackland Prairie region of Texas. Mesquite trees on 1 watershed were killed by hand application of 1 liter of diesel oil to the base of each tree. Removal of mesquite trees reduced evapotranspiration by $244 \mathrm{~mm}$ over a 3-year period and increased surface water runoff by $10 \%$ compared to an untreated watershed. Removal of honey mesquite had minimal effect on soil water in the surface soil profile during the growing season. The mesquitedominated community used considerably more water from the subsurface than did the herbaceous vegetation (Richardson et al. 1979).

The effect of shrub communities on components of the water budget of western rangelands is not fully understood, and is poorly understood on mesquite-dominated rangelands in south Texas. The objectives of this study were to: (1) quantify the components of the water budget; and (2) evaluate the seasonal water use by mesquite-dominated shrub clusters, grass interspaces, and bare soil in south Texas.

\section{Study Area and Climate}

The research area is located in Jim Wells County approximately $20 \mathrm{~km}$ south of Alice, Tex., on the Texas Agricultural Experiment Station, La Copita Research Area. Mean elevation of the 1,093 ha research area is $76 \mathrm{~m}$ above sea level. Normal rainfall for the site is $704 \mathrm{~mm}$, of which $493 \mathrm{~mm}$ (70\%) usually falls from April through September. Average annual snowfall is less than $5 \mathrm{~mm}$. Convection-type storms of high intensity occur about 30 days a year primarily during the summer months (Orton 1969 , and Minzenmayer 1979). Mean annual temperature is $22.4^{\circ} \mathrm{C}$ and the mean frost free period is 289 days (Minzenmayer, 1979).

The research site is located on a Delfina fine sandy loam (1$3 \%)$-Miguel fine sandy loam (1-3\%) soil complex, and is classified as a sandy loam range site. The soil closely resembles a Miguel fine sandy loam soil. The Miguel soil series is classified as a fine, mixed, hyperthermic, Udic Paleustalf. The Miguel soil series is in hydrologic group D.

The Rio Grande Plains of southern Texas have been classified as a Prosopis-Acacia- Andropogon-Setaria savannah (Kuchler 1964). The potential plant community is an open grassland with $90 \%$ of the area's cover composed of grasses and $10 \%$ of forbs and woody shrubs (Minzenmayer 1979). Presently, the landscape is comprised of a matrix of shrub clusters and grass interspaces with $40 \%$ of the area occupied by shrub clusters. Shrub clusters range in size and complexity from a single mesquite tree with an average canopy area of $1.7 \mathrm{~m}^{2}$ to dense shrub clusters with up to 15 woody species and an average canopy area of $56 \mathrm{~m}^{2}$. Species that commonly occur within the shrub clusters are honey mesquite, brasil (Condalia hookeri Hook), spiny hackberry (Celtis pallida Torr.), lime prickly ash (Zanthoxylum fagara (L.) Sarg.), Agarito (Berberis trifoliota Moric.), Texas persimmon (Diospyros texana Scheele), Texas colubrina (Colubrina texensis (T. \& G.) Gray), and wolfberry (Lycium berlandieri Dunal.). Many of the more productive grasses such as thin paspalum (Paspalum setaceum Michx.), root bristlegrass (Setaria geniculata (Lam.) Beauv.), and windmillgrass (Chloris verticillata Nutt.) have been replaced by red lovegrass (Eragrostis secundifola Presl.), red grama (Bouteloua trifida Thurb.), threeawn (Aristida spp. von Wolf), and common grassbur (Cenchrus echinatus L.). Taxonomic nomenclature for grasses follows Gould (1975) and for shrubs Scifres (1980).

\section{Methods}

Six dense shrub clusters and 3 grass interspace areas within a 5ha enclosure were encircled within non-weighing lysimeters in the summer of 1984. The average canopy area of the shrub clusters was $30 \mathrm{~m}^{2}$ and the shrub clusters were organized around a central mesquite tree (average basal diameter $0.2 \mathrm{~m}$ and $4.9 \mathrm{~m}$ tall). Mean species density was 60 shrubs per cluster. The nonweighing lysimeters were constructed by trenching around the perimeter of the treatment area to a depth of $2.5 \mathrm{~m}$. The inside wall of the trench was double lined with plastic and the trenches were back-filled. Each lysimeter was approximately $5 \mathrm{~m}$ by $7 \mathrm{~m}$ long with the long axis parallel to the slope. Three shrub clusters were cleared by hand slashing and the debris was removed (hereafter referred to as bare soil). The area was sterilized with tebuthiuron' $\mathrm{N}$-[5-(1,1-dimethylethyl)-1,3,4-thiadiazonal-2-yl)]$\mathrm{N}, \mathrm{N}^{\prime}$ - dimethylurea $(0.75 \mathrm{~kg}$ ai $/ \mathrm{ha})$ to prevent regrowth of herbaceous and woody vegetation. The remaining shrub clusters were left undisturbed.

Fiberglass sheets, $0.3 \mathrm{~m}$ tall, were used to form the sides and upper end of each lysimeter. Fiberglass sheets were glued to the plastic lining and inserted $0.1 \mathrm{~m}$ into the soil, creating a $0.2 \mathrm{~m}$ high border. A flume was constructed on the down-slope side to measure surface runoff. Four 2-m-long neutron access tubes were installed in each lysimeter in June of 1984. Soil water content was monitored with a calibrated neutron moisture depth gauge approximately once every 2 weeks. Volumetric water content $(\%)$ was measured at depths of $0.075,0.15,0.30,0.60,0.90,1.20$, 1.50 , and $1.80 \mathrm{~m}$.

A weather station was installed in a herbaceous vegetation clearing near the lysimeters. Weather variables measured were total rainfall and rainfall intensity with a standard rain gauge and tipping bucket, respectively, maximum and minimum temperature, and solar radiation. Normal rainfall based on the period of record from 1950-1980 was calculated from data collected in Alice, Tex.

Potential evapotranspiration $\left(\mathrm{ET}_{\mathrm{p}}\right)$ was estimated with the

'Product name provided for convenience of the reader and does not imply or constitute an endorsement by USDA. 
Jensen-Haise equation (1963) as:

$$
E T_{p}=T-(0.014 T-0.37) R_{s} / 580
$$

where $T$ is daily mean air temperature in degrees Fahrenheit and $\mathrm{R}_{\mathrm{s}}$ is solar radiation in langleys. Evapotranspiration was calculated by the water budget method as the residual of precipitation minus runoff and drainage, and any change in water stored in the store profile.

Estimation of percolation required that several soil attributes such as particle size distribution (texture), organic carbon (\%), bulk density $\left(\mathrm{g} \mathrm{cm}^{-3}\right)$, gravimetric water content $(\mathrm{g})$, porosity (E; $\%$ ), soil moisture desorption curves, and saturated and unsaturated hydraulic conductivity ( $\mathrm{mm} \mathrm{hr}^{-1}$ ) be determined for each horizon in the lysimeters. Approximately $3 \mathrm{~kg}$ of homogenized soil, integrated over the entire soil horizon, was collected from the outside wall of the lysimeter. The soil was air dried and passed through a $0.002 \mathrm{~m}$ sieve.

The mean of 2 subsamples of the soil was used to test for differences in organic matter and hydraulic conductivity within each horizon across treatments. Bulk density was determined from a $0.011 \mathrm{~m}^{3}$ soil core removed from the center of each horizon along the outer wall of the lysimeters. A single subsample of homogenized soil was used to determine particle size distribution. Particle size distribution was measured by hydrometer method (Bouyoucos 1962). Organic carbon and bulk density were determined by the Walkley-Blake method (Broadbent 1965) and the core method (Blake 1965).

The mean of 2 gravimetric water content samples at each soil depth and tension were used to develop soil moisture desorption curves following methods outlined by Klute (1965a). Gravimetric water content was determined at $0.01,0.03,0.1,0.3,0.5$, and 1.5 MPa. Changes in volumetric water content $\left(\mathrm{O}_{\mathrm{v}}\right)$ over time at 1.5 and $1.8 \mathrm{~m}$ were estimated by taking the mean of 4 volumetric water content samples with a neutron probe at each sample date. The estimation of porosity and conversion of gravimetric to volumetric water contents followed methods outlined by Brady (1974). Unsaturated hydraulic conductivity was estimated for the soil at 1.5 and $1.8 \mathrm{~m}$ (Campbell 1974) as:

$$
\mathrm{K}=\mathrm{K}_{\mathrm{S}}(\mathrm{E} / \mathrm{OV})^{\mathrm{s}+2}
$$

where $b$ is the slope of the line from a $\log -\log$ transformation of the relationship between water potential $(\mathrm{MPa})$ and $\mathrm{O}_{v}$. Saturated hydraulic conductivity was determined as outlined by Klute (1965b).

The mean unsaturated hydraulic conductivity value between 1.5 and $1.8 \mathrm{~m}$ was then used in a one dimensional Darcy's law equation to estimate the potential percolation for each sample date.

$$
D=K \quad \frac{\partial H}{\partial Z}
$$

Where $\mathrm{D}$ is the total water movement (percolation) over the time period (hr), $\mathrm{K}$ is the unsaturated hydraulic conductivity of the soil, $\mathrm{H}$ is the difference in volumetric water content at 1.5 and $1.8 \mathrm{~m}$, and $\mathrm{Z}$ is the difference in height at the 2 depths. To estimate the total percolation of water between sample dates, the mean percolation rate between 2 successive sample periods was utilized. Percolation was calculated as the period of time (hr) between sample dates multiplied by the mean percolation rate.
Ten 0.5 by $0.5 \mathrm{~m}$ plots were used to determine a monthly leaf area index of the herbaceous vegetation inside the lysimeters using the 10-point frame technique (Levy and Madden, 1933). Leaf area index was estimated as equal to the number of hits on live vegetation divided by the total number of pins lowered on the plot. Plots inside each lysimeter were permanently marked and were evaluated at monthly intervals. Leaf area index of the dominant shrubs within the shrub clusters were determined by using dimensional and regression analysis techniques (Kirmse and Norton, 1985; Ludwig et al., 1975). The dimensional analysis technique estimated total leaf biomass for a shrub at a point in time. Leaf biomass was estimated at 6 times during the study. Leaf area $\left(\mathrm{cm}^{2}\right)$ of the shrubs was determined by using a leaf area meter. A regression relationship was established to predict leaf area from leaf biomass. Leaf area index for the shrub clusters was then estimated by multiplying the estimated leaf weight times the appropriate leaf area equation, summing the total leaf area and dividing by the surface area of the lysimeter.

Root densities in the soil profiles were estimated by counting the number of roots in a single 0.1 by $0.1 \mathrm{~m}$ quadrat per soil horizon. The quadrat was located in the center of each horizon along the outside wall of the lysimeter. Roots were divided into 4 size classes based on diameter to facilitate counting: 1) $<1 \mathrm{~mm} ; 2$ ) $>$ $1<2 \mathrm{~mm} ; 3)>2<5 \mathrm{~mm}$; and 4) $>5 \mathrm{~mm}$.

The soil profile was divided into 3 soil layers for analysis of soil water content. The soil layers were $0-0.6 \mathrm{~m}, 0.6-1.2 \mathrm{~m}$, and $1.2-1.95 \mathrm{~m}$ and were chosen to evaluate the influence of evaporation (0-0.6 m), depth of root penetration of grass interspace (1.2 $\mathrm{m})$ and depth of roots in the shrub clusters $(1.95 \mathrm{~m})$. Analysis of variance was used to test for differences in treatment means for soil water, evapotranspiration, runoff, and drainage $(P<0.05)$. Where appropriate, means were separated using Tukey's mean separation test $(P<0.05)$ (Steel and Torrie 1980).

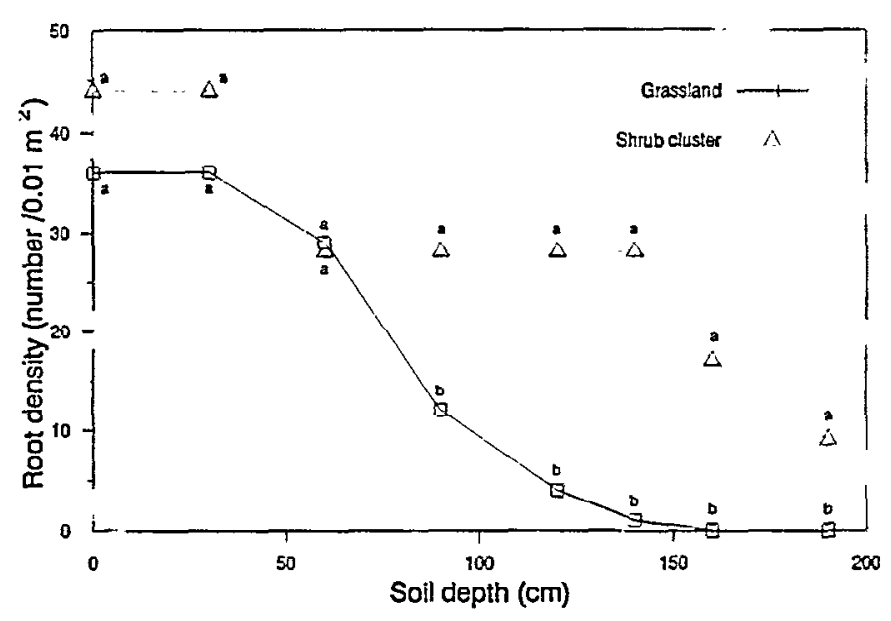

Fig. 1. Mean root density (number per $0.01 \mathrm{~m}^{2}$ ) for grass interspaces and shrub clusters, La Copita Research Area, Alice, Tex. Mean root density with the same letter within depth are not significantly different $(P<0.05)$ based on Tukey's mean separation test. 
Table 1. Physical soil characteristics of bare sandy clay loam soil, grass interspaces, and shrub clusters, La Copita Research Area, Alice, Tex.

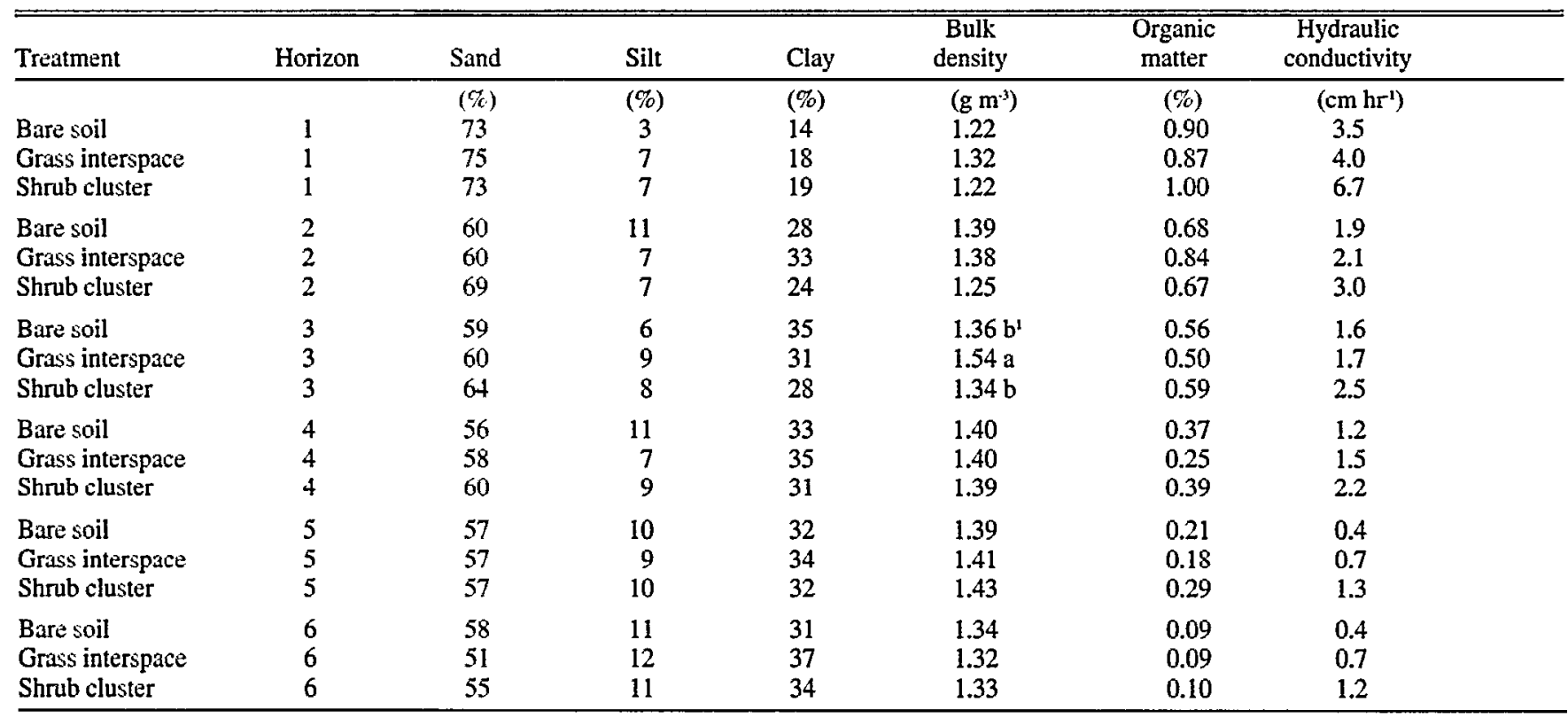

Means for bulk density in the third horizon are significantly different $(P \leq 0.05)$ based on Tukey's mean separation test.

\section{Results and Discussion}

\section{Suils}

There were minimal differences in physical attributes of the soils from bared areas, grass interspaces, and shrub clusters. The only significant difference attributable to location occurred with bulk density (Table 1). Soils in the grass interspaces had significantly higher bulk density in the third soil horizon than did soil from either the shrub clusters or the bared areas. Greater soil bulk density in the grass interspaces supports field observations of a more highly developed argillic horizon in the grass interspaces.

\section{Root Density}

Use of soil water by vegetation is a function of root density and rooting depth. Shrubs developed both surface lateral roots and relatively deep tap roots. Roots of the woody plants penetrated to $2 \mathrm{~m}$, although the majority $(83 \%)$ of their roots were in the top $1.2 \mathrm{~m}$ of the soil profile (Fig. 1). Annual grass and forb roots extended to a depth of $1.2 \mathrm{~m}$. The majority (95\%) of the annual grasses' roots were in the upper $0.9 \mathrm{~m}$ of the soil profile, and no grass or forb roots were found below $1.4 \mathrm{~m}$. There was no significant difference in root densities of the shrub cluster and grass interspaces from 0 to $0.65 \mathrm{~m}$. From 0.9 to $2 \mathrm{~m}$ the density of woody plant roots beneath the shrub clusters was significantly greater than the density of grass roots in the grass interspaces.

\section{Evapotranspiration}

Between August and December, 1984, $310 \mathrm{~mm}$ of rainfall was recorded at the site (Fig. 2). There was no significant difference in soil water content among the 3 treatments at the beginning of the study (Fig. 3). Evapotranspiration from the bare soil was significantly lower than that from either the shrub clusters or the grass interspaces (Table 2 and Fig. 4). There was no significant difference in annual evapotranspiration between the shrub clusters and grass interspaces. Lower evapotranspiration rates of the bare soil resulted in a significant difference in stored soil water between the bare soil and the shrub clusters by the beginning of November (Fig. 3). Soil water contents of the grass interspaces were intermediate. No deep drainage was estimated to have occurred within any of the treatments in 1984.

Annual rainfall for 1985 was $125 \%$ of normal precipitation (last 30 years). The study area received $243 \%$ of normal rainfall in the first 6 months of the year. Rainfall exceeded potential evapotranspiration in December, 1984 and January, February, and May, 1985. In contrast to the wet spring, the summer was extremely dry (19\% of normal rainfall). Rainfall in the fall was approximately half of normal rainfall. This distribution provided the opportunity to determine the effect of evapotranspiration during periods of above normal rainfall (January-June), drought (July and August), and a period of below normal rainfall (September-

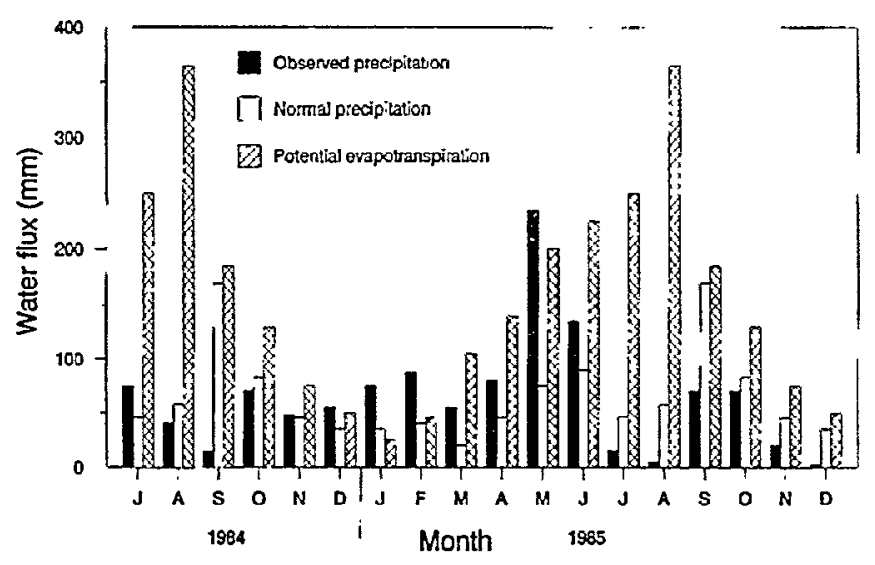

Fig. 2. Monthly rainfall (mm), long term normal monthly rainfall (mm), and potential monthly evapotranspiration (mm) for the $\mathbf{L a}$ Copita Research Area, Alice, Tex. 
Table 2. Water budget ( $\mathrm{mm}$ ) for bare sandy clay loam soil, grass interspaces, and shrub clusters, La Copita Research Area, Alice, Tex.

\begin{tabular}{|c|c|c|c|c|c|c|}
\hline Year & Treatment & Rainfall & $\begin{array}{c}\text { Evapo- } \\
\text { transporation }\end{array}$ & Runoff & Drainage & $\begin{array}{l}\text { Change in } \\
\text { soil water }\end{array}$ \\
\hline \multirow{4}{*}{1984} & & $(\mathrm{~mm})$ & $(\mathrm{mm})$ & $(\mathrm{mm})$ & $(\mathrm{mm})$ & $(\mathrm{mm})$ \\
\hline & Bare soil & 310 & $208 b^{3}$ & $31 \mathrm{a}$ & $0 \mathrm{a}$ & $71 \mathrm{a}$ \\
\hline & $\begin{array}{l}\text { Grass inter- } \\
\text { space }\end{array}$ & 310 & $298 \mathrm{a}$ & $3 b$ & $0 \mathrm{a}$ & $9 \mathrm{~b}$ \\
\hline & Shrub cluster & r 310 & $330 \mathrm{a}$ & $3 \mathrm{~b}$ & $0 \mathrm{a}$ & $-23 c$ \\
\hline \multirow[t]{3}{*}{1985} & Bare soil & 887 & $643 b$ & $84 a$ & $78 \mathrm{a}$ & $247 \mathrm{a}$ \\
\hline & $\begin{array}{l}\text { Grass inter- } \\
\text { space }\end{array}$ & 887 & $833 a$ & $28 \mathrm{~b}$ & $22 \mathrm{~b}$ & $5 \mathrm{~b}$ \\
\hline & Shrub cluster & r 887 & 881 a & $19 b$ & $0 \mathrm{~b}$ & $-13 b$ \\
\hline
\end{tabular}

Means followed by the same letter are not significantly different $(P \leq 0.05)$ based on Tukey's mean separation test.

\section{December).}

Evapotranspiration accounted for $73 \%, 94 \%$, and $99 \%$ of rainfall for 1985 received by the bare soils, grass interspaces, and shrub clusters, respectively (Table 2 ). This corresponds with annual evapotranspiration rates as a percentage of rainfall for other semiarid grass and woodland plant communities (90-147\%) (Rowe and Reimann 1961, Gifford 1975, and Carlson et al. 1990). Average annual daily evapotranspiration values were 2.4 , 2.3 , and $1.8 \mathrm{~mm} /$ day for the shrub clusters, grass interspaces, and bare soil, respectively. Average daily evapotranspiration for the grass interspaces and shrub clusters compares favorably with daily evapotranspiration rates from grasslands (1.4-4.2 $\mathrm{mm} /$ day) in Colorado and Texas (Lauenroth and Sims 1976, and Carlson et al. 1990) and mesquite dominated rangelands in Arizona (1.6-2.5 $\mathrm{mm} /$ day) and Texas (0.5-5 mm/day) (Gatewood et al. 1950, Trombel 1977, and Dugas and Mayeux 1991).

Potential evapotranspiration is usually twice actual evapotran-

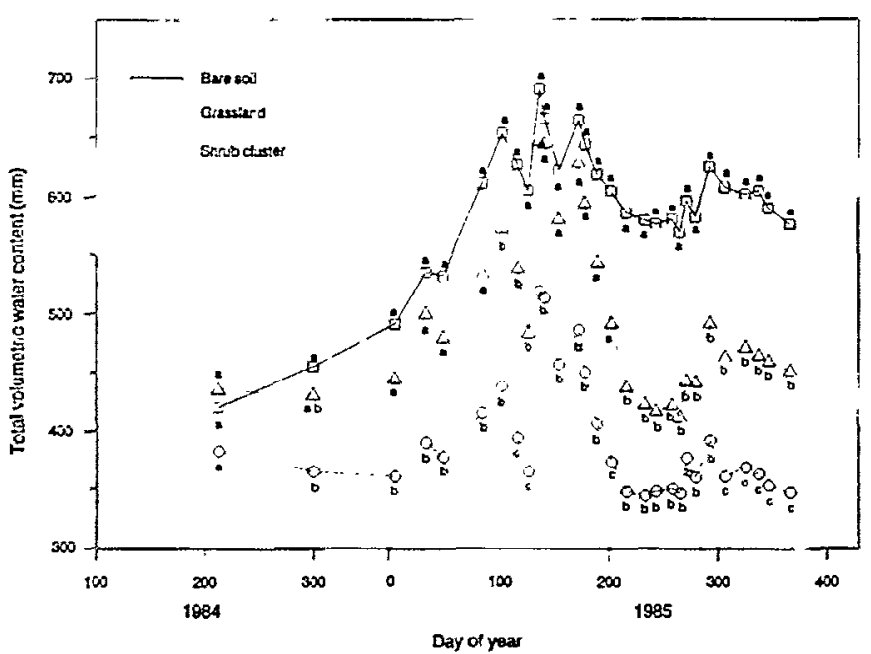

Fig. 3. Mean volumetric soil water content (mm) for bare sandy clay loam soil, grass interspaces, and shrub clusters, La Copita Research Area, Alice, Tex. Means followed by the same letter by date are not significantly different $(P<0.05)$ based on Tukey's mean separation test.
Table 3. Annual and seasonal daily evapotranspiration (mm day ${ }^{-1}$ for bare sandy clay loam soil, grass interspaces, and shrub clusters, La Copita Research Area, Alice, Tex.

\begin{tabular}{|c|c|c|c|c|}
\hline \multirow[b]{2}{*}{ Treatment } & \multirow[b]{2}{*}{ Annual } & \multicolumn{3}{|c|}{ Precipitation regime } \\
\hline & & $\begin{array}{c}\text { Above normal } \\
(1 / 85-6 / 85)\end{array}$ & $\begin{array}{l}\text { Drought } \\
(7 / 85-8 / 85)\end{array}$ & $\begin{array}{c}\text { Below normal } \\
(9 / 85-12 / 85)\end{array}$ \\
\hline & $\left(\mathrm{mm}\right.$ day $\left.{ }^{*}\right)$ & $\left(\mathrm{mm}\right.$ day $\left.{ }^{1}\right)$ & $\left(\mathrm{mm}\right.$ day $\left.^{-1}\right)$ & $\left(\mathrm{mm}\right.$ day $\left.^{-1}\right)$ \\
\hline Bare soil & $1.8 \mathrm{a}^{1}$ & $2.4 \mathrm{~b}$ & $1.1 \mathrm{c}$ & $1.3 \mathrm{a}$ \\
\hline $\begin{array}{l}\text { Grass inter- } \\
\text { space }\end{array}$ & $-2.3 \mathrm{a}$ & $2.9 \mathrm{ab}$ & $2.9 \mathrm{a}$ & $1.2 \mathrm{a}$ \\
\hline $\begin{array}{l}\text { Shrub } \\
\text { cluster }\end{array}$ & $2.4 \mathrm{a}$ & $3.4 \mathrm{a}$ & $1.8 \mathrm{~b}$ & $1.5 \mathrm{a}$ \\
\hline
\end{tabular}

Means followed by the same letter are not significantly different $(P \leq 0.05)$ based on Tukey's mean separation test.

spiration in south Texas and poiential evapotranspiration may be greater than 3 times evapotranspiration during dry years (Dugas and Ainsworth 1983). Annual evapotranspiration did not differ significantly between the shrub clusters and the grass interspaces (Table 2). There was a significant difference in the pattern of soil water use and seasonal evapotranspiration (Fig. 3 and 4). Average daily evapotranspiration rate from the shrub clusters was significantly greater than that from the bare soil during the spring (Table 3). Average daily evapotranspiration rates from the grass interspaces was similar to the shrub clusters and the bare soil. Dugas and Mayeux (1991), also working in Texas, reported that evapotranspiration was similar between grass and mesquite dominated landscapes when soil water availability was high.

Average daily evapotranspiration from the grass interspaces during the drought was significantly greater than that from the shrub clusters or bare soils (Table 3). Wan and Sosebee (1991) also reported substantial variability in transpiration rates for honey mesquite between wet and dry periods. Average daily evapotranspiration of shrub clusters was significantly greater than the daily evapotranspiration of the bare soils. The lower evapo-

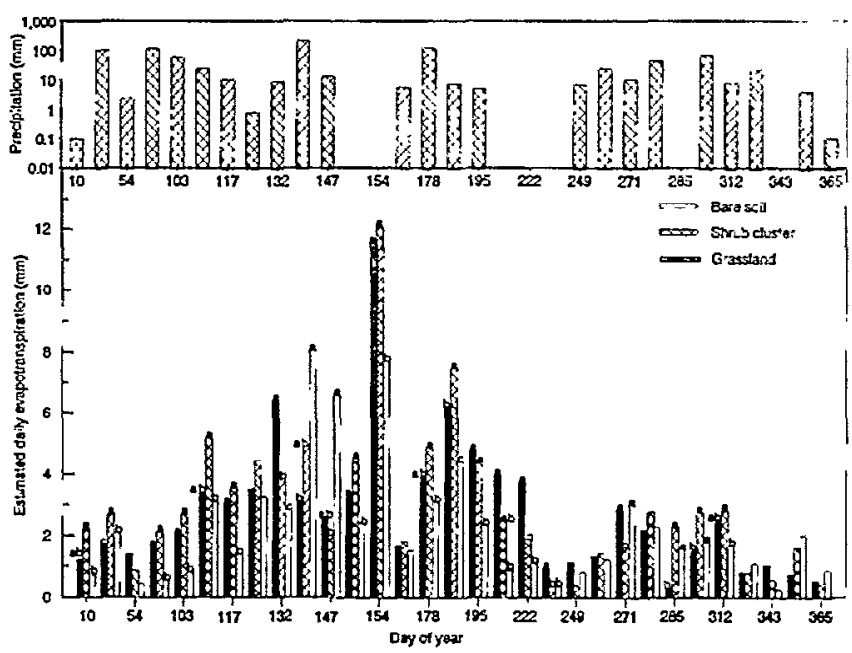

Fig. 4. Mean estimated daily evapotranspiration rate (mm) between sample dates and cumulative precipitation between sample dates for sandy clay loam soil, grass interspaces, and shrub clusters, La Copita Research Area, Alice, Tex. Means followed by the same letter by date are not significantly different $(P<0.05)$ based on Tukey's mean separation test. 
transpiration rate of the grass interspaces during the spring resulted in a significant difference in total soil water content between the shrub clusters and grass interspaces from January through the middle of August (Fig. 3). Soil water content of the grass interspaces at the initiation of the drought was $150 \%$ higher than the previous year. Annual grasses and forbs in the grass interspaces utilized this stored soil water to compensate for the reduction in rainfall to sustain higher evapotranspiration rates and leaf area than the shrub clusters. Shrub cluster's leaf area decreased by $50 \%$ with a corresponding decrease in evapotranspiration rates $(47 \%)$ in response to the reduced water availability during the drought. By September the grasses had utilized the available soil water and leaf area had decreased $90 \%$ in the grass interspaces.

A similar study using non-weighing lysimeters to contrast evapotranspiration from mesquite, herbaceous, and bare soil was initiated in northern Texas in 1986 (Carlson et al. 1990). They found that evapotranspiration was greater from bare soil than from the vegetated sites during an extended dry period. They attributed the increased evapotranspiration from the bare soil to 2 factors. The bare soil had more available water within the soil profile at the initiation of the drought than the vegetative treatments and to differential soil cracking between treatments. The vegetated sites had more canopy and litter cover than the bare soil treatment which reduced the depth of soil cracking during the extended dry period. In contrast, deep cracking was observed within the bare soil which allowed evaporation to occur from deeper within the soil profile (up to $0.8 \mathrm{~m}$ ).

Daily evapotranspiration rates of all 3 vegetation treatments were similar from September through the end of the year. Stored soil water was similar between the grass interspaces and shrub clusters in September. With the onset of fall rains the shrub clusters responded with an immediate increase in evapotranspiration rate and significantly reduced the stored soil water. There was a 3-week lag in evapotranspiration rates from the senescent grass interspaces as new leaf area was produced in the fall. Lower evapotranspiration rates of the bare soil and grass interspaces during the fall resulted in a significant increase in stored soil water content over the shrub clusters. This study and the data reported by others indicate that mesquite and mesquite-dominated shrub clusters are facultative phreatophytes.

The higher evapotranspiration rate and the reduction of stored soil water beneath the shrub clusters can be attributed in part to higher interception losses. Although there was no direct measurement of canopy and litter interception during the study, the interception rate of the shrub clusters is estimated to be approximately $15 \%$ of annual rainfall based on work in other shrub dominated plant communities. Annual interception losses for chaparral communities in California range from 8 to $20 \%$ of annual rainfall (Rowe 1948, Hamilton and Rowe 1949, and Corbett and Crouse 1968). Thurow et al. (1987), working in central Texas, estimated that for oak mottes, midgrass, and shortgrass dominated areas, canopy interception of annual rainfall was $25 \%, 18 \%$, and $11 \%$, respectively.

\section{Soil Water}

Although annual evapotranspiration was not significantly different between the shrub clusters and the grass interspaces, there was a significant difference in the pattern of soil water use. Total soil water content was similar for all 3 treatments at the beginning of the study in August of 1984 (Fig. 3). By January of 1985 soil water content was significantly greater in the grass interspaces and bare soil areas than the shrub clusters. Soil water content of the bare areas was significantly greater than that of the shrub clusters for the remainder of the study. Soil water content of the grass interspace was significantly greater than that of the shrub clusters from January through the middle of July. Soil water content of the grass interspaces was similar to that of the shrub clusters during the drought. In the fall, the reduced evapotranspiration rate of the grass interspaces resulted in significantly more water being stored in the soil profile beneath the grass interspaces than the shrub clusters.

Sturges (1983) found that grass in areas where sagebrush had been controlled used more water from the 0 to $0.9 \mathrm{~m}$ soil layer that did vegetation on the untreated sagebrush site. However, the sagebrush used more water than did the grass from the total soil profile (0-1.8 m). Johnson (1970) reported that aspen extracted water to a depth of $3 \mathrm{~m}$, while herbaceous-covered areas extracted water to a depth of only $1.2 \mathrm{~m}$. In the bare soil control area evaporation was limited to the surface $0.6 \mathrm{~m}$ of the soil profile.

Grass interspace had significantly more water in the surface soil profile $(0-0.6 \mathrm{~m})$ than the shrub clusters for the first 6 months of 1985 (Table 4). Soil water contents in the surface soil profile beneath grass interspaces and shrub clusters were similar during the drought and both were significantly less than the bare soil. Bare soil contained significantly more water in the subsoil (0.6$1.2 \mathrm{~m}$ ) than the shrub clusters for the entire year (1985) but was similar to the grass interspace during the first 6 months of the year. Soil water contents in the grass interspaces were significantly greater than the shrub clusters at the beginning of the year. By the end of the drought the soil water contents in the subsoil beneath the grass interspaces and the shrub clusters were similar. Water content of the lower soil profile $(1.2-1.95 \mathrm{~m})$ did not differ significantly among vegetative treatments throughout the year. Bare soil accumulated significantly more water by January than the shrub clusters did, and this difference was maintained for the remainder of the study.

\section{Runoff}

Runoff is often assumed to be zero on arid and semiarid range-

Table 4. Mean seasonal (1985) soil water content (mm) for bare sandy clay loam soil, grass interspaces, and shrub clusters, La Copita Research Area, Alice, Tex.

\begin{tabular}{lcccc}
\hline \hline \multirow{2}{*}{ Soil depth } & Season & Bare soil & Grass interspace & Shrub cluster \\
\cline { 3 - 5 }$(\mathrm{mm})$ & & $(\mathrm{mm})$ & $(\mathrm{mm})$ & $(\mathrm{mm})$ \\
$0-0.6$ & Jan.-July & $150 \mathrm{a}^{1}$ & $153 \mathrm{a}$ & $121 \mathrm{~b}$ \\
& Aug.-Sep. & $132 \mathrm{a}$ & $94 \mathrm{~b}$ & $79 \mathrm{~b}$ \\
& Oct.-Dec. & $145 \mathrm{a}$ & $118 \mathrm{~b}$ & $87 \mathrm{c}$ \\
\multirow{5}{*}{$0.6-1.2$} & Jan.-July & $234 \mathrm{a}$ & $221 \mathrm{a}$ & $167 \mathrm{~b}$ \\
& Aug. Sep. & $229 \mathrm{a}$ & $191 \mathrm{~b}$ & $145 \mathrm{c}$ \\
& Oct.-Dec. & $224 \mathrm{a}$ & $165 \mathrm{~b}$ & $137 \mathrm{~b}$ \\
\multirow{4}{*}{$1.2-1.95$} & Jan.-July & $235 \mathrm{a}$ & $193 \mathrm{ab}$ & $150 \mathrm{~b}$ \\
& Aug.-Sep. & $237 \mathrm{a}$ & $189 \mathrm{~b}$ & $144 \mathrm{~b}$ \\
& Oct.-Dec. & $222 \mathrm{a}$ & $165 \mathrm{~b}$ & $137 \mathrm{~b}$ \\
\hline
\end{tabular}

'Means followed by the same letter are not significantly different $(P \leq 0.05)$ based on Tukey's mean separation test. 


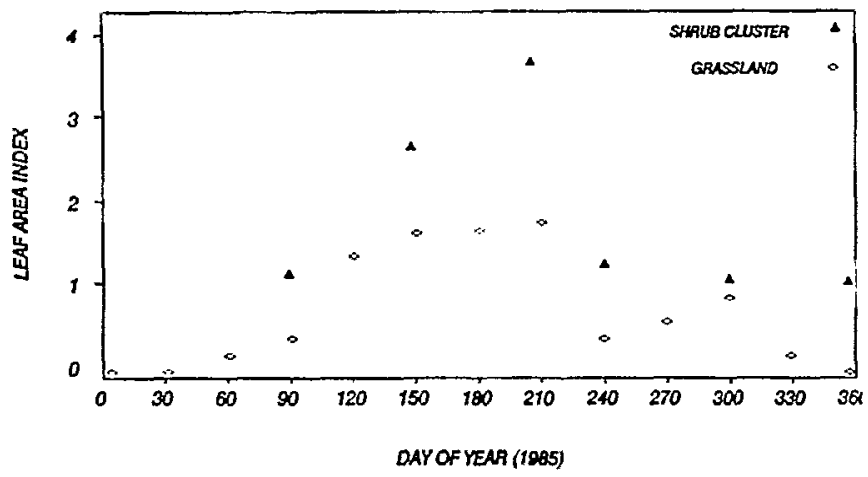

Fig. 5. Mean estimated leaf area index for grass interspaces and shrub clusters, La Copital Research Area, Alice, Tex.

lands (Lauenroth and Sims 1976, Wight et al. 1986, and Gee and Kirkham 1984). Measured annual surface runoff accounted for 1 to $10 \%$ of rainfall in 1984. Runoff from the bare soil was significantly greater than from either the shrub clusters or grass interspaces. There was no difference in runoff between the shrub clusters and grass interspaces in 1984. Annual surface runoff from the shrub clusters, grass interspaces, and bare soil was 1,3 , and $10 \%$, respectively, of rainfall in 1985 . Surface runoff was significantly greater from bare soil than from either the grass interspaces or the shrub clusters in 1985. Annual surface runoff from the grass interspaces was $32 \%$ greater than that from the shrub clusters although there was no statistical difference. The 2 largest rainfall events (>100 mm) occurred within a 5-day period in May, 1985. The average rainfall intensity of these 2 storms was $48 \mathrm{~mm} / \mathrm{hr}$. The surface runoff from the grass interspace areas from these 2 storms was significantly greater $(60 \%)$ than that from the shrub clusters. More than $50 \%$ of the surface runoff, regardless of vegetation cover, was the result of these two large rainfall events.

Grass and shrubs intercept a significant portion of incident rainfall (Rao 1987, Thurow et al. 1987, Calheiros De Miranda and Butler 1986, Tromble 1983, Young et al. 1984, Burgy and Pomerory 1958, Corbett and Crouse 1968, and Hamiltion and Rowe 1949) and thus reduce the impact of falling raindrops. Raindrops impinging directly on a bare soil surface dislodge soil particles which clog soil pores and increase surface runoff (Osborn 1954). Depending on the plants' morphological characteristics and growth form, much of the intercepted rainfall is channeled to the base as stemflow (Young et al. 1984, Glover et al. 1962, and Gwynne 1966). Litter accumulation at the base of the shrubs alters the microclimate resulting in increased root density and macroporosity, and prevents crusting of the soil surface. Initially, there were micro-depressions throughout all three vegetation treatments and the soil surface was granule. After the first several rainfall events a surface crust (2-3 mm thick) formed on the bare soil. Micro-depressions were filled with sediment after the first large rainfall event $(>20 \mathrm{~mm})$, creating a uniform gradient to the flume on the bare soil.

In the grass interspaces and shrub clusters the plants aided microrelief development and stability and prevented crusting of the soil surface. Numerous debris dams were noted in both the grass interspace and shrub clusters. Micro-depressions and debris dams increased retention time of water on the soil surface and decreased surface runoff. The increase in surface runoff from the bare soil was attributed to a reduction in infiltration rate, detention storage and surface roughness caused by soil crusting, and the erosion and leveling of the coppice dunes associated with the shrubs.

\section{Drainage}

Deep drainage from the bared soils was significantly greater than that from soils with vegetative cover and is attributed to a wetter profile from reduced total evaporation and not due to differences in macropores. The quantity of water lost through deep percolation was similar for the grass interspaces and the shrub clusters from January through April 1985. Deep drainage began in the grass interspaces in late May and continued through July. The hypothesis that water reaches depths below active root uptake in the grass interspaces is supported by the presence of soil mottling in the lower portions of the soil profile. No soil mottling was present beneath the shrub clusters or the bare soil. No deep drainage occurred beneath the shrub clusters during the study. Deep drainage beneath the bared soil areas began in late February and continued throughout the remainder of the year. When the soil water content was above $35 \%$ (by volume) in the lower soil profile, deep percolation occurred. Conditions favorable for initiation of percolation were prolonged periods of above normal rainfall during the dormant and early growing season. Only $20 \mathrm{~mm}$ of water was added to the lower soil profile of the shrub clusters. More than $80 \mathrm{~mm}$ of water was added to the lower soil profile within the grass interspaces, including $22 \mathrm{~mm}$ of water lost through deep percolation.

\section{Summary and Conclusions}

Shrub clusters responded more quickly to available soil water in both the spring and fall than did the grass interspaces. Shrub clusters transpired water whenever soil water was available. Shrub cluster transpiration rate was greater than the unsaturated flow rate, thus precluding any substantial downward movement of water into the lower soil profile. Winter and early spring rainfall was more effective than either summer or fall rainfall in recharging the soil profile. Maximum recharge of the soil profile occurred when rainfall exceeded potential evapotranspiration. High potential evapotranspiration demand during the summer and fall prevented recharge of the lower soil profile, regardless of vegetative cover. Evapotranspiration rates were greatest following rainfall events and higher from the grass interspaces than from the shrub clusters through the first 2 months of drought. Higher evapotranspiration rates of the grass interspaces during the summer was a function of the greater quantity of available soil water at the beginning of the drought. Evaporation from the bare soil was limited to the surface $0.6 \mathrm{~m}$ of the soil profile.

Soil water was extracted first from the upper horizons of the soil profile regardless of vegetative cover. As the surface horizon dried out, the water was extracted from progressively lower horizons. Once the water was beyond the active root zone in the grass interspaces, it continued to percolate as unsaturated flow and was not available for evapotranspiration. Evapotranspiration and 
runoff were essentially the same for the grass interspaces and shrub clusters. Elimination of the shrub clusters and all the associated vegetation significantly increased water yield by $16 \%$ and decreased evapotranspiration by $28 \%$ compared to the shrub clusters.

These results imply that no net change in evapotranspiration, runoff or drainage would occur if shrubs are replaced by deep rooted perennial grasses in south Texas. Increasing water yields in south Texas through vegetation manipulation is marginal and limited to those years when rainfall exceeds potential evapotranspiration.

\section{Literature Cited}

Bedunah, D.J., and R.E. Sosebee. 1984. Forage response of mesquite-buffalograss community following range rehabilitation. J. Range Manage. 37:483-487.

Blake, G.R. 1965. Bulk density. p. 374-392. In: C.A. Black (ed), Methods of Soil Analysis. Amer. Soc, of Agron, Ser. No. 9. Madison, Wis.

Bosch, J.H., and J.D. Hewlett, 1982. A review of catchment experiments to determine the effect of vegetation changes and water yield and evapotranspiration. J. Hydro. 55:3-23.

Bouyoucos, C.J. 1962. Hydrometer method improved for making particle size analysis of soil. Agron. J. 54:464-465.

Brady, N.C. 1974. The Nature and Property of Soils. MacMillan Pub. Co., Inc., New York, N.Y.

Broadbent, F.E. 1965. Organic matter. p. 1397-1400. In: C.A. Black (ed), Methods of Soil Analysis. Amer. Soc. of Agron. Ser. No. 9. Madison, Wis.

Brock, J.H., R.H. Hass, and J.C. Shaver. 1978. Zonation of herbaceous vegetation associated with honey mesquite in north central Texas. p. 187189. In: D.N. Hyder (ed), Proc. First Int. Rangelands Congr. Soc. Range Manage., Denver, Colo.

Burgy, R.H., and C.R. Pomeroy. 1958. Interception losses in grassy vegetation. Trans. Amer. Geophys. Union. 39:1095-1100.

Calheriros De Miranda, R.A., and D.R. Butler. 1986. Interception of rainfall in a hedgerow apple orchard. J. Hydrology. 87:245-253.

Campbell, G.S. 1974. A simple method for determining unsaturated conductivity from moisture retention data. Soil Sci. 117:311-314.

Carlson, D.E., T.L. Thurow, R.W. Knight, and R.K. Heitschmidt, 1990. Effect of honey mesquite on the water balance of Texas Rolling Plains rangeland. J. Range Mlanage. 43:491-496

Corbett, E.S., and R.P. Crouse. 1968. Rainfall interception by annual grass and chaparral.... Losses compared. USDA, For. Ser. Res. Paper PSW-48. Pacific Southwest For. and Range Exp. Sta, Berkely, Cal.

Dugas, W.A. and C.G. Ainsw orth. 1983. Agroclimatic Atlas of Texas. Part 6. potential Evapotranspiration. Texas Agr. Exp. Sta. Pub. MP 1543, College Station, Tex.

Dugas, W.A., and H.S. Meyeux, 1991. Evaporation from rangeland with and without honey mesquite. J. Range Manage. 44:161-170.

Gatewood, J.S., T.W. Robinson, B.R. Colby, J.D. Helm, and L.C. Halpeny. 1950. Use of water by bottom-land vegetation in the lower Safford valley of Arizona. U.S. Geol. Surv. Water Supply Paper. 1103.

Gee, G.W., and R.R. Kirkham. 1984. Transport assessment--Arid: Measurement and prediction of water movement below the root zone. Presented at the sixth Annual DOE LLWMP, Participants information meeting, Denver, Colo. 11-13 September.

Gifford, G.F., 1975. Approximate annual water budget of two chained pinyon-juniper sites. J. Range Manage. 28:73-74.

Glover, P.E., J. Glover, and M.D. Guynne. 1962. Light rainfall and plant survival in east Africa. II. Dry grassland vegetation. J. Ecol. 50:199-206.

Gould, F.E., 1975. The Grasses of Texas. Texas A \& M University Press, College Station, Tex.

Griffin, R.C., and B.A. McCarl, 1989. Brushland management for increased water yield in Texas. Water Res. Bull. 25:175-186.

Gwynne, M.D. 1966. Plant physiology and the future. p. 59-64. In: W. Davis and C.L. Skidmore (ed), Tropical Pastures. Faber and Faber. London.

Hamilton, E.L., and P.B. Rowe. 1949. Rainfall interception by chaparral in Califomia. USDA and Califomia Department Natural Resources. Division of Forestry. Unnumbered publication.

Hibbert, A.R. 1979. Managing vegetation to increase flow in the Colorado river Basin.USDA. For. Ser. Gen. Tech. Rep. RM-66, Rocky Mt. For. and Range Exp. Sta., Ft. Collins, Colo.

Hibbert, A.R., 1983. Water yield improvement potential by vegetation management on western rangelands. Water Res. Bull. 19:375-381.

Heitschmidt, R.K., R.D. Schultz, and C.J. Scifres. 1986. Herbaceous biamass dynamics and net primary production following chemical control of honey mesquite. J. Range Manage. 39:67-71.

Heitcshmidt, R.K. and S.L. Dowhower, 1991. Herbage response following control of honey mesquite within single tree lysimeters. J. Range Manage. 44:144-149.

Jensen, M.E., and H.R. Haise, 1963. Estimating evapotranspiration from solar radiation. Proc. ASCE, J. Irrigation and Drainage Division 89:15-41.

Johnson, R.S. 1970. Evapotranspiration from bare, herbaceous, and aspen plots. A check on a former study. Water Res. Res. 6:324-327.

Kirmse, R.D., and B.E. Norton. 1985. Comparison of reference unit method and dimensional analysis methods for large shrubby species in the Caatinga woodlands. J. Range Manage. 38:425-427.

Knoop, W.T., and B.H. Walker. 1985. Interaction of woody and herbaceous vegetation in southem African savanna. J. Ecol. 73:235-253.

Klute, A.L. 1965a. Water diffusity. p. 262-274. In: C.A. Black (ed), Methods of Soil Analysis. Amer. Soc. of Agron. Ser. No. 9. Madison, Wis.

Klute, A.L. 1965b. A laboratory measurement of hydraulic conductivity of saturated soils. p. 210-221. In: C.A. Black (ed), Methods of Soil Analysis. Amer. Soc. of Agron. Ser. No. 9. Madison, Wis.

Kuchler, A.W. 1964. The potential natural vegetation of the conterminous United States. Amer. Geographical Soc. New York, N.Y.

Lauenroth, W.K., and P.L. Sims, 1976. Evapotranspiration from a shortgrass prairie subjected to water and nitrogen treatments. Water Res. Research 12:437-442.

Levy, E.B., and E.A. Madden, 1933. The point method of pasture analysis. New Zealand J. Agr. 46:267-279.

Ludwig, J.A., J. F. Renolds, and P.D. Whitson. 1975. Size-biomass relationships of several Chiuahuan desert shrubs. American Midland Naturalist. 94:451-461.

Minzenmayer, F. E., 1979. Soil survey of Jim Wells County, Texas. USDA, Soil Conservation Service, p. 111.

Orton, R.B., 1969. The Climate of Texas. In: Climate of the States, Volume II- Westem States including Alaska and Hawaii. Water Information Center, Inc., Port Washington, N.Y.. p. \$71- 891 .

Osborn, B. 1954. Soil splash by raindrop impact on bare soil. J. Soil and Water Conserv. 9:33-49.

Rao, A.S. 1987. Interception losses of rainfall from cashew trees. J. Hydrology. 90:293-301.

Rechenthin, C.A., and H.N. Smith, 1964. Grassland restoration the Texas brush problem. USDA, Soil Conservation Service, p. 27.

Richardson, C.W., E. Burnett, and R.W. Bovey, 1979. Hydrologic effect of brush control on Texas rangelands. ASAE Transactions 22:315-319.

Rowe, P.B. 1948. Influence of woodland chaparral on water and soil in central California. USDA and California Department Natural Resources. Division of Forestry. Unnumbered publication.

Rowe, P.B., and L.F. Reimann. 1961. Water use by native brush, grass, and grass-forb vegetation. J. For. 17:175-181.

Scifres, C.J. and D.B. Polk. 1974. Vegetation response following spraying a light infestation of honey mesquite. J. Range Manage. 27:462-465.

Scifres, C.J., 1980. Brush Management, Principles and Practices for Texas and the Southwest. College Station, Tex.

Steel, R.G.D., and J.H. Torrie, 1980. Principles and procedures of statistics a biometeric approach. McGraw-Hill Book Company, New York, N.Y.

Sturges, D.L. 1983. Long-term effect of big sagebrush control on vegetation and soil water. J. Range Manage. 36:760-765.

Thurow, T.L., W.H. Blackburn, S.D. Warren, and C.A. Taylor. 1987. Rainfall interception by midgrass, shortgrass, and live oak mottes. J. Range Manage. 40:455-460.

Tromble, J.M. 1977. Water requirements for mesquite (Prosopis juliflora). J. Hydrol. 4:171- 179.

Tromble, J.M. 1983. Interception of rainfall by tarbush. J. Range Manage. 36:525-526.

Wan, C. and R.E. Sosebee. 1991. Water relations and transpiration of honey mesquite on 2 sites in west Texas. J. Range Manage. 44:156-160.

Walter, H. 1971. Natural savannas. Ecology of tropical and subtropical vegetation. Oliver and Boyd, Edinburg, U.K.

Wight, J.R., C.L. Hanson, and K.R. Cooley, 1986. Modeling evapotranspiration from sagebrush-grass rangeland. J. Range Manage. 39:81-85.

Young, J.A., R.A. Evans, and D.A. Eash. 1984. Stemflow on western juniper (Juniperus accidentalis) trees. Weed Sci. 32:320-327. 